\title{
Medieval Opinions on the Spanish School of Hebrew Poetry and its Epigones
}

\author{
ARIE SCHIPPERS
}

$\mathrm{I}$ N HIS CHAPTER ON THE Andalusian writer Yehudah al-Harizi (b. II65 in Toledo; d. I225 in Aleppo), Israel Zinberg states that:

Al-Harizi was not only a poet but also a literary critic. In the third, eighteenth, and also partly in the forty-sixth maqama, he provides an interesting historical-critical characterisation of the Hebrew poetry of the Spanish-Arabic period up to his time.

In Zinberg's view, al-Harizi calls the generation in which he lived 'the generation of epigones'. He then quotes as follows from the eighteenth maqama of the Tahkemoni:

Since Solomon Ibn Gabirol left the world and Moses Ibn Ezra, Jehudah Halevi, and Abraham Ibn Ezra died, the well of poetry has dried up, inspiration has disappeared, and God's spirit no longer manifests itself. None of their successors can compare with them. We backward ones, like beggars, gather the crumbs and refuse that have fallen from their table. We hasten day and night over the ways trodden by them, but we cannot equal them. ${ }^{\mathrm{I}}$

Although it was perhaps unfair of Zinberg to attribute to Harizi the views of his protagonists, ${ }^{2}$ it is probable that this was indeed his attitude

I. I. Zinberg, A History of Jewish Literature, transl. and ed. by B. Martin. Vol. I: The ArabicSpanish Period (Cleveland I972) p. I70 ff.; J. Blau and J. Yahalom, Masse`e Yehudah (Jerusalem 2002), p. 177.

2. Another poet from Provence who lived a century later, Abraham ha-Bedersi (second half of the i3th century) in his catalogue of poets entitled Cherev ha-Mithappekhet ('The Turning Sword') professes the opinion that poetry in his time has deteriorated. He considered his to be a time of epigones; see A. Schippers, 'Les poètes juifs en Occitanie au moyen age: le catalogue d'Abraham de Béziers', in Revue des Langues Romanes I03 (1999) (Présence juive en Occitanie médiévale), p. I-25. 
to the epigonism of his contemporaries, given the remarks he makes about the decline of proficiency in Hebrew and the use of rhymed prose instead of true poetry, as composed by the first generations of Hebrew poets in Andalusia.

The present discussion examines medieval opinions about epigonism, especially those found in al-Harizi's maqamat, ${ }^{3}$ and how these may be evaluated against the background of medieval Hebrew poetry in the Mediterranean, focusing particularly on the life and work of Yehudah alHarizi. My ideas about the latter's life and work have changed in recent years, since the discovery by Sadan 4 of an Arabic work on Syrian poets of the time, which included remarks on the life and work of al-Harizi. Yahalom and Blau's edition's of al-Harizi's Arabic and Hebrew travel maqamat also contributed to this development, as did the recent publications by the late Rina Drory on maqamat and the relation between Arabic and Hebrew literature. ${ }^{6}$ Ayelet Oettinger-Salamah's dissertation on the satirical mode and Christian influences in the Book of Tahkemoni falls outside the scope of the present article. ${ }^{7}$

Sefer Tahkemoni was written in the style of the classical Arabic maqama genre developed by al-Hamadhani (967-1007) in Persia and by al-Hariri (I054-II22) in Iraq. As a result, the Tahkemoni has been considered the definitive model of the Arabic-influenced classical Hebrew maqama. In an earlier work, Mabberot Itiel, al-Harizi translated and adapted several of al-Hariri's maqamat.

In the introductory chapters and dedications of the Tahkemoni, al-Harizi airs his views about the decline of proficiency in Hebrew, especially in the East, contrasting this with Andalusia's golden age of Hebrew poetry. In the third, eighteenth and forty-sixth maqamat,

3. A. Schippers, 'The Hebrew maqama (Chapter 8.I-8.I.8.3)', in: J. Hämeen-Anttila, Maqama: A History of a Genre (Wiesbaden 2002), p. 305-306.

4. J. Sadan, 'Un intellectuel juif au confluent de deux cultures: Yehudah al-Harizi et sa biographie arabe', in: M. Fierro, Judios y musulmanes en al-Andalus y el Magreb, contactos intelectuales, actas reunidas (Madrid 2002), p. I05-I5I; this is a revised version of: idem, 'Rabbi Judah alHarizi as a Cultural Junction' [Hebrew], Pe'amim 68 (1996), p. I6-67.

5. Blau and Yahalom, op. cit.

6. R. Drory, Models and Contacts, Arabic Literature and its Impact on Medieval Jewish Culture (Leiden 2000).

7. A. Oettinger-Salama, A Research of The Satirical Mode in Yehudah al-Harizi's 'Book of Tahkemoni', dissertation (Haifa 2003-2004). 
al-Harizi evaluates the poets of those generations, and the generations of epigones and patrons who receive both praise and blame for their reception of Hebrew poetry. In this respect, some interesting remarks by Blau and Yahalom as well as Sadan based on recently discovered sources relating to poetry and its reception, and to al-Harizi as a Hebrew and Arabic poet and maqamist, offer a new perspective on the question of epigonism.

Al-Harizi dedicates Sefer Tahkemoni to two persons: Samuel ben al-Barquli in the introduction, ${ }^{8}$ and Yoshiyahu ben Yishai in the first maqama. ${ }^{9}$ The Tahkemoni also includes an Arabic dedication to Shadid al-Dawla 'Abd al-Qadir of Aleppo and his son Abu Nasr. ${ }^{10}$ In the introduction $^{\text {II }}$ al-Harizi describes how he came to compose his Hebrew maqamat: he was awakened from his 'sleep of folly' and took on the task of reviving the Hebrew language, since the holy tongue was in decline, having been abandoned by its people who had come to prefer Arabic. Al-Harizi explains that he was greatly influenced by al-Hariri's Arabic maqamat, which proved that other peoples existed who cherished their language and preserved it with care, unlike the people of Israel, who had abandoned their native tongue. He was therefore determined to demonstrate in his own maqamat both the wealth of the Hebrew language and its suitability for literary expression in various different genres.

The second Hebrew dedication ${ }^{12}$ is actually the first maqama of the Tahkemoni. As related by Heman Ha-Ezrahi - the fictional narrator presented by al-Harizi in the introduction - the author finds himself in the company of the protagonist of the maqama, Heber ha-Qeni (also presented in the introduction), debating with him surrounded by a group of Hebrew men of letters. Heber, a young 'Hebrew' man, ${ }^{13}$ states that Arabic is the most beautiful of all languages, as al-Hariri's work proves. The author, al-Harizi, now comes to the defence of the Hebrew language: Hebrew was originally the most beautiful language, but the Jews were

8. Al-Harizi, Tahkemoni, ed. Toporowski (Tel Aviv 1952), p. 4-I8; Al-Harizi, The Tahkemoni of Judah al-Harizi, transl. by V.E. Reichert (Jerusalem I965-1973), p. 23-43.

9. Al-Harizi (1952), p. 19-30.

Io. Drory (2000), p. 22I-223.

II. Al-Harizi (1952), p. 4-I8; al-Harizi (1965-1973), p. 23-43.

I2. Al-Harizi (1952), p.19-30; Al-Harizi (1965-1973), p.44-58.

13. Elsewhere Heber is an old man. Similar inconsistencies are found in the Arabic maqamat. 
exiled and adopted the languages of the people among whom they lived, forgetting Hebrew. Yet even what little remains of the Hebrew language is enough to compose beautiful literature. The young Hebrew man objects that he has never seen any of these splendid Hebrew works. The author replies that he proposes to show that it is possible to compose a work in Hebrew, although the real problem is that, given the lack of demand among the Jews in the East for works of this nature, there is little point in producing them. The young man agrees, but urges him to ignore this generation's folly and write a book which will convince everyone of the superiority of the Hebrew language. The young man also suggests that the book should be dedicated to Yoshiyahu hen Yishai and his two sons, David and Shelomo. The author accepts the suggestion and composes fifty Hebrew maqamat demonstrating the beauty of the Hebrew language. The young man takes his leave of the author and it is at this point that he turns out to be Heber ha-Qeni, the hero of all the maqamat.

Rina Drory refers to a third preface in Arabic, the contents of which express similar sentiments about the decline in the knowledge and understanding of Hebrew among Jews in the East. The following extracts are from Drory's translation of Harizi's Arabic preface: ${ }^{14}$

I have noticed that most of the Israelite community in these lands of the East are devoid of the Hebrew language and denuded of its beautiful garments. If one of them were asked about a Hebrew word, it would seem as if he were being addressed in a foreign language. [...] I consider this to be one of the most terrible misfortunes to come upon our nation during our exile. This disease continues to spread among them, to the extent that most of them are never capable of putting the [Hebrew] letters together. [...] I then composed fifty Hebrew maqamat: I embellished them with pearls of the Prophets' words and studded them with precious stones of Biblical phrases so that they turned out like embroidered gowns or well-ordered necklaces. [...] If he persists in reading these maqamat, Hebrew will run smoothly off the tip of his tongue, and the bridle of his eloquence and clear expression will be slackened. [...] When the honourable head [of the community] Sadid al-Dawla 'Abd al-Qadir, son of the heads of the Academy and the glory of the community of Aleppo,

I4. Drory (2000), p. 22I-223. 
bestowed his generosity, charity, goodness and grace upon my tongue - even if my ink flowed from the oceans and my pen were made out of trees, I would never have been able to express my thanks for his kindness - I thought it right to adorn this compilation with his name, unique as he is in his generation, and with the name of his honourable and precious son, Abu Nasr.

Al-Harizi reproached the poets of the East not for their lack of Arabic, but for their ignorance of proper Hebrew, unlike the first Andalusian Hebrew poets, whose audience was well acquainted with Hebrew: in some of the maqamat on the subject of poetry, al-Harizi contrasts the former situation in the West with the present situation in the East.

In the third maqama ${ }^{\mathrm{IS}}$ of the Tahkemoni, which has the Arabic title maqamat shu'ara' al-Andalus ('the poets of Andalusia'), ${ }^{16}$ the narrator Heman-ha-Ezrahi begins with a survey of Hebrew poetry of Andalusia, complemented occasionally by the itinerant Heber ha-Qeni. He praises the Hebrew poems of Andalusia for being like men, while poems elsewhere are like women.

Similar sentiments are expressed in the eighteenth maqama of the Tahkemoni, entitled maqamat 'asr al-shu'ara' al-ibraniyyin ('The time of the Hebrew poets'). ${ }^{17}$ The narrator Heman visits Jerusalem, where he meets the elect of Israel. The discussion turns to how the foundations of the house of poetry were first laid, and which Jews have drawn from the well of poetry. Those present observe that from earliest times the Arabs were naturally endowed with the gift of poetry, but they do not know when the spirit of poetry was revealed to the Jews, nor who was the first to open its gates.

Then an old man, the protagonist Heber, began to answer them by saying: You should know that the admirable poetry which is filled with pearls has been given to the Arabs as a heritage [...] they walked through its palaces, and provided it with a roof and set up the doors thereof [cf. Nehemiah 3:3]. They occupy the highest rank above the poets of the world [...]. Although there are in every people poets and

15. A. Schippers, Spanish Hebrew Poetry and the Arabic Literary Tradition, Arabic Themes in Hebrew Andalusian Poetry (Leiden 1994), p. 65-69.

I6. See also H.J. Schirmann, Hash-Shirah ha-ibrit bi-Sfarad u-bi-Provens (Tel Aviv 1956), IIa, p. IO3 $\mathrm{ff}$ (the third Maqamah).

I7. Ibid., IIa, p. I3I ff. 
men who occupy themselves with the crafting of poems, all their poems are of no use and no avail compared with the poems of the Arabs [Ismaelites]...

He continues that according to Scripture (Obadiah I:20), the diaspora of Jerusalem was in Spain (Sefarad). Spain was pleasantly located in the West, while Babylon (the other centre of the Jewish diaspora) was in the East at the same degree of latitude: Spain and Babylon being two pillars of a single building of which the world should be proud. It is due to its location that knowledge of poetry spread to Spain. The Jews there were skilled in its techniques.

Then the old man describes when Hebrew poetry first began to appear in Andalusia, namely around 4700 (940 BCE). A patron who contributed significantly to the development of Hebrew poetry was Yishaq, the son of Hasday ibn Shaprut. Yishaq ibn Khalfon also receives praise: he opened the doors of poetry for the 'Hebrews' (i.e. Jews who composed poetry in Hebrew). Then Samuel ha-Nagid is mentioned, and Solomon ibn Gabirol, 'after whom no poet like him arose'. As Zinberg noted, those who tried to imitate him failed: 'They did not even reach the dust of his feet because of the vigour of his words and the force of his utterances'. Solomon ibn Gabirol, observes Heber, died at the age of twenty-nine.

After Yehudah ha-Levi, says the protagonist, Hebrew poetry began to decline. He goes on to explain why Hebrew poetry failed to flower in Jewish communities outside Spain. There are no good poets in these communities, he points out. He mentions the Arab countries, whose poets are unknown to the twentieth-century reader. He considers northern France and Greece. He divides the poets into five categories. Solomon ibn Gabirol is in the highest rank; in the second rank stands the poetry of Yehudah ha-Levi, Abraham and Moses ibn Ezra. The rest of the Spanish poets, including Yosef ibn Zabbarah, are third rank. In the fourth rank are the noble poets of the East; the fifth rank comprises the contemporary Hebrew poets of Damascus, Egypt, Aleppo, Iraq, Baghdad and Ma'arrah. The protagonist now turns to the terrible imitations produced in the East, such as those of a poet of Irbil in Iraq called Ben ha-Shekwi, who tried to surpass Moses ibn Ezra's Sefer ha-'Anaq.

Al-Harizi's comments on the epigones of later generations, expressed by his heroes in the eighteenth maqama, also occur in the third maqama. 
Throughout his travels in the East, al-Harizi never found an audience to match his ideal: the Jews of Andalusia who were supposedly both interested in Hebrew poetry and understood the language. He says as much in the introduction and the first maqama, as well as the Arabic preface to the maqamat. He was evidently concerned about the difficulty of finding an audience for his maqamat. This is apparent from his reworking of the forty-sixth chapter of the Tahkemoni on the 'Appraisal of the People' (Maqamat mizan ahl al-'asr fi dhikr afdal ahl al-diyar wa-kirami-ha wawasf ba'di khisal liyami-ha $)^{18}$ in the light of his later experiences with patrons in the East. Al-Harizi also discusses this in an Arabic maqama; both were recently published in Blau and Yahalom's Masse'e Yehudah. These works provide an insight into the state of the literary Hebrew and how works in Hebrew were received at the Jewish courts in the East, prompting al-Harizi's opinion about the poor quality of Hebrew poetry in the East. Both versions of Chapter 46 are published by Blau and Yahalom, ${ }^{19}$ as is the Arabic Al-rawdah al-aniqah ('The pleasant garden'). ${ }^{20}$ They also republished the 'Chapter of the Poets' (Tahkemoni, ch. I8), ${ }^{21}$ as well as, for the first time, an autographic letter by al-Harizi, providing additional details concerning his stay in Egypt ('The Chapter of the Patrons'). ${ }^{22}$ These pieces describe more than fifty Jewish communities in Spain, Provence, Egypt, Palestine, Syria and Iraq and over two hundred prominent Jewish leaders.

Al-Harizi was apparently searching for new patrons in the East. However, he failed to win appreciation for his Hebrew work. He was disappointed in the Eastern Jewish communities: they were unwilling to pay sufficiently for his Hebrew works. Coming from the West, he was considered a stranger and his talents were not recognised. The Jews of the East were familiar with Classical Arabic literature, but they were not

I8. 'The Maqamah of the Balance of the contemporaries by mentioning the most excellent and generous of the houses and the description of some of the characteristics of the blameworthy people' also called by Blau and Yahalom, op. cit., p. 49 ff. 'The Chapter of the Appraisal of the People'. I prefer 'chapter' where Blau and Yahalom use 'gate'. Another Hebrew translation suggests 'The Balance of the Generation'.

19. Blau and Yahalom, op. cit., p. 49-76.
20. Blau and Yahalom, op. cit., p. 91-168.
21. Blau and Yahalom, op. cit., p. I69-188.
22. Blau and Yahalom, op. cit., p. 77-90. 
as familiar with Hebrew court literature as the Jewish intellectuals of the West.

In a recently discovered Arabic biographical work, Sadan found that Yehudah al-Harizi eventually turned his back on Hebrew poetry and, remaining in the East, devoted himself to Arabic verse. Sadan also offers a theory about the originality of themes in Arabic poetry (see below), from which I am inclined to conclude that epigones are not possible in Arabic poetic theory. ${ }^{23}$ The characteristic of Hebrew poetry, with its contrast between the first generations of Hebrew poets of the Andalusian West, and the generations of epigones in the East, is not possible in Arabic poetry, since there is no contrast between generations and regions: time and space play no role.

Sadan's new discoveries about al-Harizi's life are based on an Arabic biographical work by Ibn al-Sha"âr al-Mawsili (II97-I256) about contemporary poets called Qalâ'id al-jumân fi farâid shu'arâ' hâdha alzamân ('A necklace of precious gems treating the delightful treasures of the poets of this period'). The chapter on al-Harizi reveals that he wrote his Book of Tahkemoni in the East, where he died at the age of sixty (at Aleppo on 2 or 3 December 1225 ), that he never returned to Spain, that he was a tall man without a beard who spoke with a Western Arabic accent. Al-Harizi was born in Spain - probably in the Christian city of Toledo, where the Jews were still culturally Arabic - and arrived in Egypt and Syria around I2I5. Sadan calls al-Harizi a representative of the Arabic and Mudejar population. He was right of course: although al-Harizi was born in a city ruled by Christians, his cultural background was Classical Arabic and his Hebrew was in the tradition of the New Andalusian school of poetry.

Al-Harizi's Arabic audience judged the style of his Arabic verse favourably. He employed figures of speech in his poetic language that reveal the mannerisms of a later stage in poetry: the accumulation of images and a tendency towards formal symmetry. The latter may reflect a characteristic of the Arabic poetry of Andalusia, as shown by Scheindlin in his research on al-Mu'tamid's verse. ${ }^{24}$ In Andalusian Hebrew verse,

23. Sadan, op. cit. (2002), p. $135 \mathrm{ff}$.

24. R.P. Scheindlin, Form and Structure in the Poetry of al-Mu'tamid ibn 'Abbâd (Leiden 1974). 
Moses ibn Ezra demonstrates this tendency in his explanation of figures of speech taking examples from Hebrew poetry as well as Arabic examples based mainly on al-Hâtimi. ${ }^{25}$ Moses ibn Ezra and his contemporaries employ similar mannerisms in their Hebrew verse, ${ }^{26}$ even though this is usually the final stage of poetry and literature. Their new school of Hebrew poetry may have been just beginning: in fact they adopted existing Arabic poetic traditions in an eclectic fashion. Al-Harizi's verse may also have been influenced by the use of stylistic listing of figures of speech in Andalusian poetry, and indeed by al-Hariri's rhymed prose.

The following fragment from a poem mentioned by Ibn Sha"âr which al-Harizi apparently addressed to Abu'l-Fath Muhammad ibn Abi'l-Khayr ibn Abi'l-Mu'ammar ibn Isma'il al-Tabrizi - shows the use of symmetry in al-Harizi's Arabic poetry: ${ }^{27}$

--v-/--v-/--v-// or: vv-v-/vv-v-/vv-v-// [metre: kâmil]

fa-shrab bi-ardin ghâzalat-hâ muznatun/ fa-ka'annamâ hattânu-ha fattânu-hâ//

fa-ta'âshaqat wa-ta'ânaqat afnânu-hâ/ wa-tasâfahat wa-tanâwahat aghsânu-hâ//

wa-tasâkhabat wa-tajâwabat atyâru-hâ/ wa-tabâdalat wa-tadâwalat alhânu-hâ//

wa-tanassamat wa-tabassamat ayyâmu-hâ/ wa-tahallalat wa-takallalat azmânu-hâ//

bi-mudîri-hâ wa-munîri-hâ wa-mujîri-hâ/ wa-mu'îri-hâ husnan jalâhu 'iyânu-hâ//

bi-hakîmi-hâ wa-'amîmi-hâ wa-karîmi-hâ/ wa-za'îmi-hâ 'uqidat la-hu tîjânu-hâ//

Drink on a land, with which a rainy cloud holds amorous talk/ so that it looks as if its continuous drizzle is its seducer//

25. A. Schippers, 'Symmetry and Repetition as a stylistic Ideal in Andalusian Poetry. Moses ibn Ezra and Figures of Speech in the Arabic Tradition', in: M. Woidich (ed.), Amsterdam Middle Eastern Studies (Wiesbaden 1990), p. I60-I73.

26. A. Schippers, 'Manierismo e Individualidad: la poesía de Ibn Jafâyah (I058-II39), Moshe ibn Ezra (I055-II38) y Yehudah ha-Levi (IO74-II4I)', in: J. Targarona Borrás and A. Sáenz Badillos, Poesía hebrea en al-Andalus (Granada 2003), p. 173-I85; A. Schippers, 'Current Trends in the Study of Hispano-Arabic Literature, the Problem of the Distinctiveness of the Individual Andalusian Poet: the Case of the Poet Muhammad b. Idris b. Marg al-Kuhl (d. 634 H)', The Arabist, Budapest Studies in Arabic 24-25 (2000), p. I63-I74.

27. Sadan, op. cit. (2002), p. I49. 
And its branches love each other and embrace each other and its boughs shake each others hands and blow to each other from opposite sides//

And its birds raise confused noises giving each other response and their melodies are exchanged and are spread everywhere//

Its Days are breathing and smiling and its Times are bright and crowned//

By its Director and Illuminator and Protector and its Giver of Excellence which polished, when you look to it //

By its Wise, Lofty and Generous Person and Leader to whom its crowns are awarded//.

It is obvious, even to non-Arabists, that many identical word patterns are repeated. The same tendency is found in verse by other Andalusian poets. Sadan wonders whether al-Harizi exported this flowery Andalusian style. It is an interesting idea.

Also relevant to the theme of epigonism is the discussion broached by Sadan on the nature of plagiarism and the relation between lafz and ma'na (i.e., wordings and themes) in Arabic poetic theory. In an extensive excursion, Sadan notes how the outer forms of themes and ideas are developed. He presents two schemes: one with the idea or theme as the centre from which all kinds of formal variants derive; the other reflects his own preference, namely a poetical theme or idea in a certain form, developed by other poets in different forms, creating a chain of different formal elaborations.

This seems a sensible way of dealing with the question of originality versus slavish imitation in Arabic literature. There can be no epigonism in Arabic literature as long as poets take part in the same system of themes and formal elaborations. There is nothing in the procedure of later poets to differentiate them from their predecessors. Every poet makes original verse by putting new content into established forms. In this approach to Arabic poetry, time and space become irrelevant: a poet may improve on a predecessor's theme at any time or place as long as the classical Arabic system is used, even today. Clearly this is not possible in Hebrew poetry, since time, space and history are essential to its appreciation, as Yehudah al-Harizi's statements show.

What is it that makes the Hebrew system so different from its Arabic counterpart? It was not for their lack of Arabic that al-Harizi reproached the Hebrew poets of the East, but their poor command of 
Hebrew. Compared to the scholars of Andalusia, their insight into the Hebrew language and its proper use in poetry was meagre. Al-Harizi was well placed to judge and compare East and West. Moreover, he witnessed the changes that the maqamat brought to Hebrew literature: from the lyrical to the narrative.

As an Arabic poet he was not an epigone: the Arabic system of lafz and ma'na continues for ever: there is no concept of a generation of followers less skilled than their predecessors. Hebrew literature, however, is conscious of its broken traditions: time and space generate different poetry. In the classical period of Andalusian Hebrew verse, audiences in the West understood and appreciated poetry more than audiences in the East - as reflected in al-Harizi's criticism of the inability of Jews in the East to understand Hebrew poetry. Al-Harizi himself marks a new stage in the development of Hebrew belles lettres: he had reached its apogee with the rhymed prose in the style of the Arab literate al-Hariri, but its merit remained hidden since his work lacked an appreciative audience. Indeed, he may have considered himself less competent than the poets of the Andalusian tradition since the verse he inserts in his maqamat is merely occasional compared to that composed by the Hebrew poets of Andalusia. He considered himself a lesser poet in Hebrew, compared to Solomon ibn Gabirol and Yehudah ha-Levi. The distance in time and space that separates them suggests lost situations and lost skills, so that the term 'epigone' in Zinberg's rendering of al-Harizi's protagonist's speech makes sense. In time, al-Harizi was separated from the first Hebrew poets of Andalusia; in space he was confronted in the East by a public that lacked sufficient understanding of Hebrew. In the end he turned to Arabic.

Was al-Harizi indeed an epigone? As a Hebrew poet he belonged to the later generations. This makes him an 'epigone', according to his own account, as Zinberg points out. As a maqamist he was not particularly successful in his own lifetime; yet in later centuries his maqamat came to be considered classic examples of Haririan verse. Indeed, now we know that he also wrote maqamat in Arabic. He certainly does not deserve the epithet epigone as a maqamist; he was a prominent creator of classic maqamat. Neither was he an epigone as a writer of Arabic poetry, in light of the notion of literary timelessness developed by Sadan with its occasional elaborations on classical themes. In his Arabic Diwan, al-Harizi 
continues the flowery Andalusian tradition of symmetry in grammatical and word patterns. It seems, therefore, that a person can be both an epigone and at the same time a creator of a classic original work; indeed, it was as a creator of new work that al-Harizi was honoured in later centuries by historians of Hebrew literature. 